\title{
PARTISIPASI KELUARGA DALAM PENCEGAHAN PENYAKIT DIARE
}

\author{
Taamu, Sitti Rachmi M., \& Dali \\ Staf Dosen Jurusan Keperawatan Poltekkes Kemenkes Kendari
}

\begin{abstract}
Abstrak
Penelitian ini bertujuan untuk menganalisis dan menjelaskan pengaruh perilaku keluarga terhadap partisipasi keluarga dalam melakukan pencegahan penyakit diare pada anak balita di Wilayah Kerja Puskesmas Mokoau tahun 2017. Metode penelitian yang digunakan dalam penelitian ini adalah metode penelitian kuantitatif. Lokasi penelitian adalah Kota Kendari. Populasi adalah keluarga yang memiliki anak balita. Penarikan sampel dilakukan dengan teknik simple random sampling. Hasil penelitian menunjukkan bahwa Mayoritas responden memiliki partisipasi yang baik terhadap pencegahan penyakit Diare, dimana dari 71 responden terdapat 43 responden $(60,56 \%)$ memiliki partisipasi pada ketegori baik, 23 responden $(32,39 \%)$ memiliki partisipasi pada kategori cukup, dan hanya 5 responden $(7,05 \%)$ yang berada pada kategori kurang. Perilaku keluarga berpengaruh terhadap partisipasi keluarga dengan signifikan sebesar $0.036<\alpha=0,05(5 \%)$. nilai $\mathrm{R}$ sebesar 0,249 dan Nilai $R$ square sebesar 0,062 . Dengan demikian dapat disimpulkan bahwa terdapat pengaruh yang signifikan antara perilaku keluarga terhadap partisipasi keluarga dalam melakukan pencegahan penyakit diare pada balita di wilayah kerja puskesmas mokoau kota Kendari tahun 2017
\end{abstract}

Kata Kunci: Diare, partisipasi keluarga, perilaku keluarga

\section{Abstract}

This study aims to analyze and explain the influence of family behavior on family participation in preventing diarrheal disease in children under five in the Work Area of Mokoau health center in 2017. The research method used in this research is quantitative research method. The research location is Kendari City. The population is a family with children under five. Sampling is done by simple random sampling technique. The results showed that the majority of respondents had good participation in prevention of Diarrhea disease, where from 71 respondents there were 43 respondents (60.56\%) had participation in good category, 23 respondents (32.39\%) had participation in enough category, and only 5 respondents $(7.05 \%)$ are in the less category. Family behavior influenced significant family participation by $0,036<\alpha=$ $0,05(5 \%)$. $R$ value of 0.249 and $R$ square value of 0.062 . Thus it can be concluded that there is a significant influence between family behavior on family participation in preventing diarrhea disease in infants in the working area of mokoau health center Kendari City in 2017

Keywords: diarrhea, family participation, family behavior

\section{PENDAHULUAN}

Usia anak balita merupakan golongan umur yang paling rentan terhadap penyakit infeksi. Hal ini disebabkan karena pada usia tersebut merupakan masa dimana anak aktif bermain dan melakukan kontak langsung dengan lingkungan luar. Pada kondisi lingkungan luar yang kurang baik karena kotoran dan sampah yang dibuang sembarangan dapat menjadi tempat berkembang biak bakteri, parasit maupun virus yang dapat menyebabkan terjadinya penyakit infeksi pada anak balita. Salah satu penyakit infeksi yang sering terjadi pada anak balita adalah penyakit diare.

Diare adalah penyakit yang ditandai dengan bertambahnya frekuensi buang air besar lebih dari biasanya ( 3 kali atau lebih per hari) yang disertai perubahan bentuk dan konsistensi tinja dari penderita (Depkes RI, 2010). Diare adalah suatu keadaan pengeluaran tinja yang tidak normal atau tidak seperti biasanya, ditandai dengan peningkatan volume, keenceran, serta 
frekuensi lebih dari 3 kali sehari dan pada neonatus lebih dari 4 kali sehari dengan atau tanpa lendir dan darah (Hidayat, 2006).

Berdasarkan laporan World Health Organitation (WHO) tahun 2012 bahwa setiap tahun diare membunuh sekitar 760.000 anak balita di dunia. Sedangkan pada tingkat global diare menyebabkan $16 \%$ kematian sedikit lebih rendah dibandingkan dengan pneumonia, sedangkan pada tingkat regional (negara berkembang), diare menyumbang sekitar $18 \%$ kematian balita dari 3.070 juta balita (Depkes RI, 2011:33). Dari hasil laporan surveilans terpadu berbasis rumah sakit pada unit rawat jalan RS. Bhayangkara Kendari sepanjang tahun 2012 ditemukan kasus diare dari semua golongan umur sebanyak 136 kasus sedangkan jumlah kasus tertinggi berada pada golongan umur 1-4 tahun (balita) sebanyak 43 kasus atau sebesar 31,61\% (Laporan Surveilans Terpadu Berbasis Rumah Sakit Bhayangkara Kendari, 2012).

Secara teori dikatakan bahwa salah satu faktor yang berkaitan dengan tingginya kasus diare pada balita yaitu tingkat partisipasi keluarga dalam melakukan tindakan pencegahan secara maksimal. Masalah kurangnya partisipasi keluarga ini disebabkan oleh informasi yang kurang terhadap faktor-faktor yang mempengaruhi partisipasi tersebut sehingga membentuk budaya yang menyebabkan tidak mementingkan pola hidup yang sehat. Sehingga rasa ingin tahu masih kurang, khususnya dalam penanganan diare. Untuk itu rencana yang dilakukan adalah menuntun keluarga agar memahami atau mengetahui cara mengatasi masalah diare (Hidayat, 2006).

Keluarga adalah sekumpulan orang yang dihubungkan oleh ikatan perkawinan, adopsi, kelahiran yang bertujuan menciptakan dan mempertahankan budaya yang umum, meningkatkan perkembangan fisik, mental, emosional dan sosial dari tiap anggota keluarga (Duval (Dalam Setiadi, 2008: 2)). Dalam UU Kesehatan nomor 23 tahun 1992 pasal 5 menyebutkan "Setiap orang berkewajiban untuk ikut serta dalam memelihara dan meningkatkan derajat kesehatan perorangan, keluarga, dan lingkungan". Dari pasal tersebut dijelaskan bahwa keluarga berkewajiban menciptakan dan memelihara kesehatan dalam upaya meningkatkan tingkat derajat kesehatan yang optimal (Setiadi, 2008:14).

Perilaku adalah tindakan atau aktivitas dari manusia itu sendiri yang mempunyai bentangan yang sangat luas antara lain: berjalan, berbicara, menangis, tertawa, bekerja, kuliah, menulis, membaca, dan sebagainya. Dari uraian ini dapat disimpulkan bahwa yang dimaksud perilaku manusia adalah semua kegiatan atau aktivitas manusia, baik yang diamati langsung, maupun yang tidak dapat diamati oleh pihak luar (Notoatmodjo, 2003). Kebersihan pada ibu dan balita terutama dalam hal perilaku mencuci tangan sebelum makan, merupakan kebiasaan yang baik. Sebagian besar kuman infeksi diare ditularkan melalui jalur fecal-oral berupah cairan atau benda tercemar dengan tinja misalnya air minum dan makanan. Kebiasaan dalam kebersihan berperan penting dalam penularan kuman penyakit diare, dengan mengubah kebiasaan dari tidak mencuci tangan sebelum makan menjadi selalu mencuci tangan akan dapat memutuskan rantai penularannya.

\section{METODE PENELITIAN}

Penelitian ini dilaksanakan di Puskesmas Mokoau Kota Kendari. Desain penelitian yang digunakan dalam penelitian ini adalah metode penelitian kuantitatif. Populasi dalam penelitian ini adalah semua keluarga yang memiliki balita yang berada di wilayah kerja puskesmas mokoau kecamatan kambu kota Kendari yang berjumlah 3691 yang tersebar 4 kelurahan, yakni kelurahan kambu, Mokoau, Padaleu, dan Lalolara. Besaran sampel dalam penelitian ditentukan dengan menggunakan rumus:

$$
\mathrm{n}=\frac{N \cdot Z^{2}(p \cdot q)}{d^{2}(N-1)+Z^{2} p \cdot q}(\text { Notoatmodjo, 2010) }
$$


Besarnya sampel dalam penelitian ini adalah 71 responden dengan kriteria:

a. Inklusi

1) Orang Tua/keluarga anak Balita

2) Berdomisili di sekitar wilayah kerja puskesmas Mokoau kecamatan Kambu.

3) Keluarga klien bersikap kooperatif

b. Eksklusi

1) Orang tua tidak memiliki anak balita

2) Orang tua/keluarga anak balita tidak bersedia menjadi responden

Pengambilan sampel dilakukan dengan teknik simple random sampling. Proses pengacakan responden dilakukan pada setiap kelurahan.

Data yang telah dikumpulkan selanjutnya akan diolah secara manual dan menggunakan komputer melalui program SPSS (Statistical Product and Service
Solution) for Windows. Teknik analisa yang digunakan adalah teknik analisa deskriptif yang digunakan untuk mendeskripsikan variabel perilaku keluarga dan partisipasi keluarga. Dan analisis statistik inferensial menggunakan analisis regresi linear sederhana untuk melihat pengaruh faktor perilaku keluarga terhadap partisipasi keluarga dalam melakukan pencegahan penyakit diare pada anak balita. Model persamaan regresi sederhana dalam penelitian ini adalah:

$$
y=a+b x+e
$$

Untuk menentukan tigkat keeratan hubungan variabel menggunakan klasifikasi guilford sebagai berikut;

\section{HASIL PENELITIAN}

Tabel 1. Karakteristik Responden di Wilayah Kerja Puskesmas Mokoau

\begin{tabular}{|c|c|c|c|c|}
\hline No & Karakteristik & Kategori & $\mathbf{f}$ & $\%$ \\
\hline A & Umur (Tahun) & & & \\
\hline 1 & $20-35$ & Resiko Rendah & 57 & 80,28 \\
\hline 2 & $36-45$ & Resiko Sedang & 14 & 19,72 \\
\hline \multirow[t]{2}{*}{3} & $<20$ atau $>45$ & Resiko Tinggi & 0 & 0.00 \\
\hline & \multicolumn{2}{|l|}{ Total } & 71 & 100 \\
\hline B & Pekerjaan & & & \\
\hline 1 & $\mathrm{IRT}$ & Tidak Bekerja & 37 & 52.11 \\
\hline 2 & Pedagang & \multirow{4}{*}{ Bekerja } & 17 & 23.94 \\
\hline 3 & Buruh & & 5 & 7.04 \\
\hline 4 & Petani & & 5 & 7.04 \\
\hline \multirow[t]{2}{*}{5} & PNS & & 7 & 9.86 \\
\hline & \multicolumn{2}{|l|}{ Total } & 71 & 100 \\
\hline C & \multicolumn{4}{|l|}{ Pendidikan } \\
\hline 1 & Tidak Sekolah & \multirow{2}{*}{ Rendah } & 2 & 2.82 \\
\hline 2 & SD & & 10 & 14.08 \\
\hline 3 & SMP & \multirow{2}{*}{ Menengah } & 19 & 26.76 \\
\hline 4 & SMA & & 21 & 29.58 \\
\hline 5 & Perguruan Tinggi & Tinggi & 19 & 26.76 \\
\hline \multicolumn{3}{|c|}{ Total } & 71 & 100 \\
\hline
\end{tabular}


Berdasarkan tabel 1 tampak bahwa mayoritas responden berumur 20 - 35 tahun dengan kategori Resiko Rendah yaitu sebanyak 57 responden $(80,28 \%)$, responden berumur 36 - 45 tahun dengan resiko sedang sebanyak 14 responden $(19,72 \%)$. Sedangkan status pekerjaan responden mayoritas tidak bekerja atau sebagai Ibu Rumah Tangga (IRT) yakni sebanyak 37 responden $(52,11 \%)$, dan sebanyak 34 responden $(47,89 \%)$ bekerja selain IRT. Adapun tingkat pendidikan responden mayoritas setingkat Pendidikan Menengah yakni sebanyak 40 responden $(56,36 \%), \quad 12$ responden (16,90\%) berpendidikan rendah dan 19 responden $(26,76 \%)$ berpendidikan tinggi

Tabel 2. Kategori Partisipasi keluarga di wilayah kerja puskesmas Mokoau

\begin{tabular}{ccc}
\hline Partisipasi Keluarga & $\mathbf{f}$ & $\%$ \\
\hline Baik & 43 & 60,56 \\
\hline Cukup & 23 & 32,39 \\
\hline Kurang & 5 & 7,05 \\
\hline \multicolumn{3}{c}{ Total } \\
Sumber: olahan data primer
\end{tabular}

Berdasarkan tabel 2 di atas dapat dilihat bahwa mayoritas responden memiliki partisipasi yang baik terhadap pencegahan penyakit Diare, dimana dari jumlah responden sebanyak 71 responden terdapat 43 responden $(60,56 \%)$ yang memiliki partisipasi pada ketegori baik, 23 responden $(32,39 \%)$ memiliki partisipasi pada kategori cukup, dan hanya 5 responden (7,05\%) yang berada pada kategori kurang.

Secara umum, deskripsi perilaku keluarga di wilayah kerja puskesmas Mokoau di sajikan pada tabel 4 . berikut.

Tabel 3. Kategori Perilaku keluarga di wilayah kerja puskesmas Mokoau

\begin{tabular}{ccc}
\hline Perilaku Keluarga & $\mathbf{f}$ & $\%$ \\
\hline Baik & 41 & 57.74 \\
\hline Cukup & 15 & 21.13 \\
\hline Kurang & 15 & 21.13 \\
\hline Total & 71 & 100 \\
\hline \multicolumn{2}{c}{ Sumber: olahan data primer }
\end{tabular}

Berdasarkan tabel 3 di atas dapat dilihat bahwa mayoritas perilaku keluarga berada pada kategori baik, dimana dari jumlah responden sebanyak 71 responden terdapat 41 responden $(57,74 \%)$ adalah keluarga dengan perilaku pada kategori baik, 15 responden (21,13\%) adalah keluarga dengan perilaku pada kategori cukup, dan 15 responden $(21,13 \%)$ adalah keluarga dengan perilaku pada kategori kurang.

\section{Analisis Inferensial}

Tabel 4. Crosstabulasi perilaku dan partisipasi keluarga melakukan pencegahan penyakit Diare

\begin{tabular}{lccccccc}
\hline & \multicolumn{7}{c}{ Partisipasi } \\
\cline { 2 - 6 } Perilaku & \multicolumn{2}{c}{ Kurang } & \multicolumn{2}{c}{ Cukup } & \multicolumn{2}{c}{ Baik } & \multirow{2}{*}{ Total } \\
\cline { 2 - 6 } & $\mathbf{f}$ & $\%$ & $\mathbf{f}$ & $\%$ & $\mathbf{f}$ & $\%$ & \\
\hline Kurang & 2 & 13.33 & 8 & 53.33 & 5 & 33.33 & 15 \\
\hline Cukup & 2 & 13.33 & 3 & 20.00 & 10 & 66.67 & 15 \\
\hline Baik & 1 & 2.44 & 12 & 29.27 & 28 & 68.29 & 41 \\
\hline \multicolumn{1}{c}{ Total } & 5 & 7.04 & 23 & 32.39 & 43 & 60.56 & 71 \\
\hline
\end{tabular}

Sumber: olahan data primer 
Table 5. Hasil Analisis Regresi

\begin{tabular}{|c|c|c|c|c|c|}
\hline Model & B & Fhitung & Sig. & $\mathbf{R}$ & R Square \\
\hline Constant & 6,959 & \multirow{2}{*}{4,552} & \multirow{2}{*}{0.036} & \multirow{2}{*}{0.249} & \multirow{2}{*}{0.062} \\
\hline Perilaku Keluarga & 0.126 & & & & \\
\hline
\end{tabular}

Dependent Variable: Partisipasi_Keluarga

Sumber: olahan data primer

Pada table 4 disebutkan bahwa perilaku keluarga yang baik sangat potensial untuk memiliki partisipasi yang baik dalam melakukan pencegahan penyakit diare. Mayoritas keluarga yang memiliki perilaku yang baik memiliki partisipasi yang baik, yaitu 41 responden dengan perilaku baik, 28 responden $(68,29 \%)$ diantara memiliki partisipasi baik, 12 responden (29,27\%) memiliki partisipasi cukup, 1 responden $(2,44 \%)$ memiliki partisipasi kurang.

Demikian pula Keluarga yang memiliki perilaku cukup, mayoritas memiliki partisipasi baik, yaitu 15 responden dengan perilaku cukup, 10 responden (66,67\%) memiliki partisipasi baik, 3 responden $(20 \%)$ memiliki partisipasi cukup, dan 2 responden $(13,33 \%)$ memiliki partisipasi kurang. Sedangkan keluarga dengan perilaku pada kategori kurang, mayoritas memiliki partisipasi yang cukup, yakni dari 15 responden dengan perilaku pada kategori kurang, 8 responden (40\%) diantaranya memiliki partisipasi yang cukup, 5 responden (33,33\%) memiliki partisipasi baik, dan 2 responden (13,33\%) memiliki partisipasi kurang.

Hasil analisis pengaruh variable bebas terhadap variable terikat disajikan pada tabel 5. Hasil analisis regresi linear sederhana menunjukan bahwa ada pengaruh yang siginifikan antara perilaku keluarga dengan partisipsi keluarga dalam melakukan pencegahan penyakit diare pada balita di Wilayah kerja puskesma Mokoau kota Kendari yang ditandai dengan nilai Signifikan sebesar $0.036<\alpha=0,05(5 \%)$. nilai $R$ sebesar 0,249 menunjukan bahwa perilaku keluarga mempunyai keeratan hubungan dengan partisipasi keluarga sebesar 0,249 satuan berada pada kategori rendah.

Nilai $R$ square sebesar 0,062 menunjukkan bahwa kontribusi perilaku keluarga terhadap partisipsi keluarga dalam melakukan pencegahan penyakit diare sebesar $6,2 \%$, sisanya dipengaruhi oleh variabel lain. Adapun persamaan regresi sederhana yang menyatakan pengaruh Perilaku Keluarga terhadap partisipasi keluarga dalam melakukan pencegahan penyakit diare pada balita di wilayah kerja puskesmas Mokoau kota Kendari adalah

$$
y=6,959+0,126 x+e
$$

\section{PEMBAHASAN}

Partisipasi merupakan suatu tindakan untuk melibatkan diri secara aktif dalam melakukan suatu kegiatan. Dalam konteks kesehatan keluarga, partisipasi dapat dimaknai dengan perhatian keluarga dalam menjamin terwujudnya kesehatan keluarga secara komprehensif atau menyeluruh. Peran aktif keluarga sangat dibutuhkan untuk menciptakan suasana yang kondusif bagi perkembangan anggota keluarganya agar terhindar dari berbagai jenis gangguan kesehatan, khususnya penyakit diare pada anak balita. Orang tua berperan besar dalam menentukan kualitas kesehatan anak melalui pengasuhan yang baik dengan cara melakukan pengelolaan berbagai aspek yang berhubungan dengan penyebab terjadinya penyakit diare pada anak. Peran orang tua dalam peneitian ini di implementasikan melalui partisipasi keluarag dalam melakukan tindakan pencegahan penyakit diare pada anak balita. Partisipasi keluarga merupakan 
variable yang dinamis, kualitas partisipasi sangat resisten terhadap berbagai faktor yang menyertai aktifitas setiap keluarga, diantaranya disebutkan dalam penelitian ini yakni Perilaku keluarga.

Hasil penelitian menunjukkan bahwa perilaku keluarga berpengaruh secara signifikan terhadap partisipasi keluarga dalam melakukan pencegahan penyakit diare pada anak balita diwilayah kerja puskesmas Mokoau kota Kendari yang ditunjukkan oleh nilai Siginifikan $\rho=0,036<$ $\alpha=0.05$. ini berarti perilaku keluarga yang baik akan meningkatkan kualitas partisipasi keluarga dalam melakukan pencegahan penyakit diare pada anak balita di wilayah kerja Puskesmas Mokoau Kota Kendari. Nilai $R$-square sebesar 0,062 menunjukkan bahwa kontribusi perilaku keluarga terhadap Partisipsi Keluarga dalam melakukan pencegahan penyakit diare sebesar $6,2 \%$, sisanya sebesar $93,8 \%$ dipengaruhi oleh variabel lainnya.

Secara deskriptif perilaku keluarga diwilayah kerja puskesmas Mokoau berada pada kategori baik. Keluarga yang berperilaku baik, cenderung memiliki partisipasi yang baik dalam melakukan pencegahan penyakit diare pada anak balita. Hal ini tergambar pada hasil penelitian yang menunjukkan bahwa sebanyak $68,29 \%$ responden yang memiliki perilaku yang baik dalam memberikan pelayanan kepada balita juga memiliki partisipasi yang baik dalam melakukan tindakan pencegahan terhadap penyakit diare, dan sisanya $29,27 \%$ memiliki partisipasi yang cukup, dan 2,44\% memiliki partisipasi yang kurang. Responden yang berperilaku cukup, $66,67 \%$ diantaranya memiliki partisipasi yang baik, sisanya sebesar $20 \%$ memiliki partisipasi yang cukup dan $13,33 \%$ memiliki partisipasi yang kurang. Sedangkan responden yang berperilaku kurang 53,33\% diantaranya memiliki partisipasi yang cukup, 33,33\% memiliki partisipasi yang baik, dan $13,33 \%$ memiliki partisipasi yang kurang.

Hasil penelitian memberikan gambaran bahwa responden cenderung memiliki partisipasi yang baik, sebab setiap kategori perilaku keluarga selalu memiliki partisipasi yang baik dengan persentase yang cukup signifikan. Bahkan pada kategori perilaku kurang, terdapat 33,33\% persen yang memiliki partisipasi yang baik dan hanya $13,33 \%$ yang memiliki partisipasi yang kurang. Hal ini memberikan gambaran bahwa responden memiliki kesadaran yang sangat baik dalam memberikan perhatian terhadap kondisi kesehatan anaknya. Kesadaran tersebut timbul sebagai manisfestasi perilaku yang merupakan keteraturan tertentu dalam hal perasaan (afeksi), pemikiran (kognisi), dan predisposisi tindakan (konasi) seseorang terhadap suatu aspek di lingkungan sekitarnya. perilaku dipengaruhi oleh beberapa faktor yang berasal dari diri individu itu sendiri, antara lain susunan syaraf pusat, persepsi, motivasi, emosi dan belajar. Maulana (2009) menjelaskan faktor perilaku ditentukan oleh tiga kelompok faktor yaitu; faktor predisposisi, faktor pendorong, dan faktor pendukung. Faktor predisposisi mencakup pengetahuan, sikap, kepercayaan (tradisi), norma sosial dan unsur-unsur lain yang terdapat dalam diri individu.

Setiap keluarga memiliki dorongan dalam dirinya sebagai buah kesadaran transendental terhadap tanggung jawabnya sebagai orang tua. Karena alasan itu, pada diri setiap keluarga akan muncul dorongan untuk memberikan perlindungan kepada anak balita terhadap berbagai ancaman kesehatan yang mungkin bisa menyerang anak sewaktuwaktu. Senada dengan itu Agustina dkk., (2016) menyatakan bahwa perilaku yang baik dipengaruhi oleh faktor internal yang terdapat pada diri indiviu. Artinya, perilaku kita pada umumnya dimotivasi oleh suatu keinginan untuk mencapai tujuan tertentu. Untuk memproteksi anak dari penyakit diare, maka orang tua balita menerapkan perilaku hidup sehat yang baik dengan cara berpartisipasi aktif dalam upaya pencegahan penyakit diare. Perilaku orang tua yang berkaitan dengan potensi 
anak terserang diare terdapat pada pola hidup bersih yang diterapkan orang tua ketika berinteraksi dengan anak balita, khususnya kebersihan fasilitas bermain maupun perlengkapan makan yang harus dijaga agar tetap higienis. Perilaku ini sangat rentan diabaikan oleh orang tua terutama bagi orang tua yang sibuk bekerja atau kurang memahami pentingnya kebersihan fasilitas balita.

Secara umum responden

menunjukkan perilaku baik dalam mewujudkan kebersihan fasilitas anak balita. Tetapi masih terdapat 15 (21,13\%) responden berperilaku kurang baik. Ini berarti masih ada keluarga yang belum memperhatikan secara detail tentang kebersihan fasilitas yang digunakan oleh anak balita. Angka tersebut masih cukup besar jika mengingat potensi terjadinya diare yang ditimbulkan akibat perilaku yang kurang baik. Kurangnya perilaku responden tersebut dapat disebabkan oleh kurangnya pengetahuan yang memadai bagi responden tentang penyakit diare. Pengetahuan dapat diperoleh melalui pendidikan atau pengalaman yang diperoleh secara langsung atau melalui informasi dari pengalaman orang lain. Adi dkk (2008) menyatakan bahwa Perilaku yang baik bisa terjadi karena pengalaman-pengalaman yang diperoleh seseorang. Artinya, seseorang dapat membentuk perilaku yang berupa antithesis dari pengalaman buruknya. Kecenderungan untuk selalu menjadi lebih baik akan mendorong seseorang tersebut berperilaku baik.

\section{KESIMPULAN DAN SARAN}

Partisipasi Keluarga dalam melakukan pencegahan penyakit diare pada anak balita di Wilayah Kerja Puskesmas Mokoau secara umum berada pada kategori baik. Faktor perilaku keluarga berpengaruh secara signifikan terhadap partisipasi keluarga dalam melakukan tindakan pencegahan penyakit diare.
Orang tua balita agar selalu mengikuti kegiatan penyuluhan yang diselenggarakan oleh pemerintah baik secara langsung maupun melalui media masa agar dapat menambah wawasan tentang pencegahan penyakit diare pada anak balita dan tumbuh kembang anak, sehingga orang tua dapat melakukan tindakan pencegahan yang maksimal terhadap penyakit diare.

\section{DAFTAR PUSTAKA}

Adi N, Bahrul I, \& Marliani, (2007). Studi Korelasi Karakteristik Dengan Perilaku Keluarga Dalam Upaya

Penanggulangan Malaria Di Kecamatan Kintap Kabupaten Tanah Laut Propinsi Kalimantan Selatan Periode September-Desember Tahun 2007. Jurnal Promosi Kesehatan Indonesia Vol. 3 / No. 1 / Januari 2008

Agustina dkk., (2016). Hubungan Pengetahuan, Sikap Dan Perilaku Ibu Yang Menikah Pada Usia Muda Dalam Pemenuhan Gizi Balita Usia 3-5 Tahun Dengan Status Gizi Balita Di Pondok Bersalin Desa Suko Jember Kec. Jelbuk Kab. Jember. Jurnal Kesehatan. Vol. 4. No. 1. Januari - April 2016

Dinas Kesehatan Provinsi Sulawesi Tenggara. (2010). Rekapitulasi Laporan Penyakit Diare tahun 2010. Kendari. , (2012). Profil Kesehatan Provinsi

Sulawesi Tenggara tahun 2012.Kendari.

Maulana, H.DJ., (2009). Promosi Kesehatan. Jakarta : EGC

Hidayat, A.A., (2006). Pengantar IImu Keperawatan Anak. Salemba Medika. Jakarta

Notoatmodjo, S. ( 2007). Promosi Kesehatan dan IImu Perilaku. Jakarta : PT. Rineka Cipta

RS. Bhayangkara, (2012). Laporan Surveilans Terpadu Berbasis Rumah Sakit. Kendari.

Setiadi, (2008). Konsep Dan Proses Keperawatan Keluarga. Yogyakarta: Graha IImu. 